\title{
An Experiment on Solid Propellant Combinations; Evaluate the Propellant Properties using Ultrasonic Impulse Measuring System
}

\author{
J.Sarathkumar Sebastin, Raghu Dev S K
}

\begin{abstract}
Impulse force is the key for all high speed aero propulsion system. Solid propellants are uncontrollable once it ignited because it has the ingredients (fuel, oxidizer) for combustion within the chamber in which they are ignited. Since an entire solid propellant motor performance depends on propellant choice, chamber pressure, and nozzle design, the evaluation of propellant properties is highly needed. In the proposed Ultrasonic Impulse measuring system, the solid propellant motor, when fired, produces a thrust force which makes a bending moment in the simply supported beam. A sensitive Ultrasonic sensor will calibrate the bending moment, proportional to the Impulse force. The effective burning time is noted. Thermocouple reading, load cell reading, and the effective burning time value is used for calculating the mass flow rate, effective exhaust velocity, and specific impulse. The different fuel - oxidizer combinations with catalysers, binders are made. The small scaled propellant motor with length $0.12 \mathrm{~m}$, Diameter $0.025 m$, Exit Nozzle Diameter $0.003 m$, Empty Motor weight 20grams are used. The Recrystallation method is used for propellant preparation. The pyrotechnic ignition is adapted. The Grain test, Rope test are carried out. We have chosen high molecular weight, and low heat of formation value propellants. There are 4 different propellant combinations are tested with the proposed impulse measuring system. The Specific impulse reading of $\mathrm{KNO}_{3}+\mathrm{C}_{12} \mathrm{H}_{22} \mathrm{O}_{11}+\mathrm{Al}$ powder combination has highest value among all the propellants. It has 87seconds of specific impulse. The proposed impulse measuring system gives the reasonable readings with minimum error. We have compared the experimental results with the theoretical results and got the specific impulse of 90 seconds. The heat of formation of potassium nitrate and sucrose combination gives a low heat of formation value. The heat of combustion value and the characteristic velocity of the solid propellant combination $\left(\mathrm{KNO}_{3}\right.$ $+\mathrm{C}_{12} \mathrm{H}_{22} \mathrm{O}_{11}+$ Al powder) are decreased.
\end{abstract}

Keywords: Impulse force, Ultrasonic Impulse Measuring System, Bending moment, Heat of formation, Characteristic velocity, Recrystallation method.

\section{INTRODUCTION}

$\mathrm{P}_{\text {ropellants impart motion to an object through the }}$

Revised Manuscript Received on December 30, 2019.

* Corresponding Author

* J.Sarathkumar Sebastin, Asst. professor, Aeronautical Engineering, Kalasalingam Academy of Research and Education, Tamilnadu, sebastinaero@gmail.com.

Raghu Dev S K, U.G. Students, Mechanical Engineering, Kalasalingam Academy of Research and Education, Tamilnadu, raghudev565@gmail.com conversion of potential energy into useful kinetic energy. There are 2 ingredients, fuel, and oxidizer, necessary in a propellant system. Physically, propellants are classified into 2 main classes, liquid propellants, and solid propellants. A solid propellant motor consists of an outer casing, igniter, nozzle, and propellant charge as shown in figure 1. The propellant charge contains all the ingredients necessary for combustion process within the chamber; it obeys the first law of thermodynamics. There are two types of solid propellants available, Mono and composite propellant. A propellant charge contains both oxidizer, and fuel in the same molecule, referred as mono propellant. Composite propellant uses potassium nitrate or sodium nitrate as the oxidizer, sulphur as binder, ferric oxide as catalyser, and with charcoal as a fuel. Composite propellant burns at higher temperature, and pressure than mono propellants. There are 4 types of solid propellant preparation techniques are available; Dry ramming, Melting/Casting, Moist pressing, and Recrystallization. In the proposed research, small scaled solid propellants are fabricated and tested. The ingredients are chosen with reference to the properties of solid propellants.

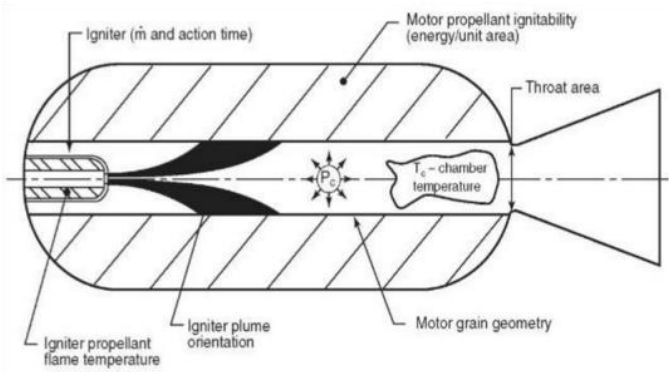

Fig.1. Solid propellant motor configuration

\section{PROPELLANT CHARGE PREPARATION}

Recrystallization method is used here for safe and easy operation. In this method of operation, the operator is not exposed to hot propellant during the cooking process. We don't need to grind or mill the ingredients, because they are soluble in water. It can be reheated and formed into grains days/months or years after preparation. It is somewhat less brittle than melt/ cast propellants. Burn rate can be adjusted somewhat by the extent of cooking. 
Chemical reaction between the fuel and oxidizer must release large amount of heat energy giving higher combustion temperature and specific impulse. The propellant must have comparatively lower molecular weight; higher density and should give high specific impulse. The products of combustion, i.e., Exhaust gas should be smokeless and colourless. The propellants should be chemically inert. It should not ignite due to slight impact or shock or pressure. Raw material must be abundantly available; must be cheap, safe to handle. Must be easy and safe to grind, mix, heat, trim, pack, and store the propellants. Also it should be practicable to cast or extrude the solid propellants in desired shape and sizes. It should be stable. The physical and chemical properties should not change during processing; should not deteriorate with time. The following propellant combinations are made for the test. (i) $\mathrm{KNO}_{3}+\mathrm{C}_{12} \mathrm{H}_{22} \mathrm{O}_{11}$ (ratio 65/35), (ii) $\mathrm{KNO}_{3}+\mathrm{C}_{12} \mathrm{H}_{22} \mathrm{O}_{11}+\mathrm{Al}$ powder, (iii) $\mathrm{KNO}_{3}+\mathrm{C}_{12} \mathrm{H}_{22} \mathrm{O}_{11}+$ Sulphur, and (iv) $\mathrm{KNO}_{3}+\mathrm{C}_{12} \mathrm{H}_{22} \mathrm{O}_{11}+$ sulphur $+\mathrm{Al}$ Powder.

\section{Recrystallization Method:}

The grain size of the ingredients is to become very small. For that, the electrical grinder/mixer is used. Fuel, oxidizer, binder, and catalyser have been taken in the appropriate ratio. For fuel and oxidiser, ratio of 35/65 and 40/60 are taken. 75\% of water is added with the mixed propellants and is heated in the electric oven. The potassium nitrate is soluble in water. While heating, the soluble rate is increased. After 1-2minutes, propellant mixer disappears in water. The mixture will be formed as paste after $35-40 \mathrm{~min}$.

The paste form of the propellant charge is stored in the propellant motor as shown in figure 2 . To avoid oxidation, it is isolated from the air.

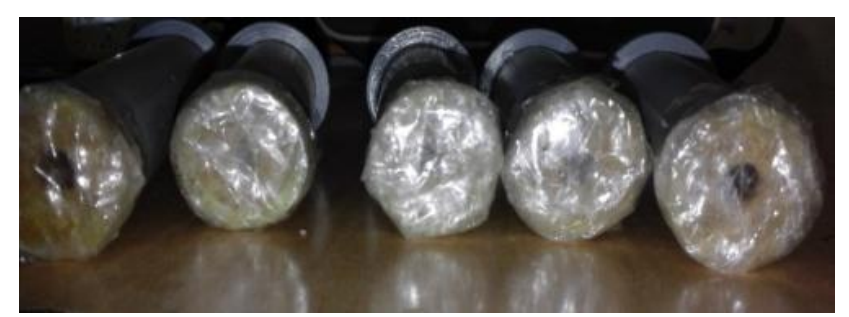

Fig.2. Stored propellant

\section{ELECTRIC IGNITER FOR PROPELLANT IGNITION:}

Radio frequency transmitter and receiver $(433 \mathrm{MHz})$ are used to control the ignition. The 5volt DC relay circuit used to synchronize the signal and ignition performance. An electric match is a device that uses an externally applied electric current to ignite a combustible compound. Figure 5 shows that, the electric match consists of a short length of high resistance wire (bridge wire) mounted across copper cladding on an electrically insulating substrate. When the ignition is needed, transmitter provides signal to the receiver. The receiver unit will control the 5VDC relay. The electric igniter is short circuited by a copper wire, so due to the heat generated on the wire, the ignition will be started.

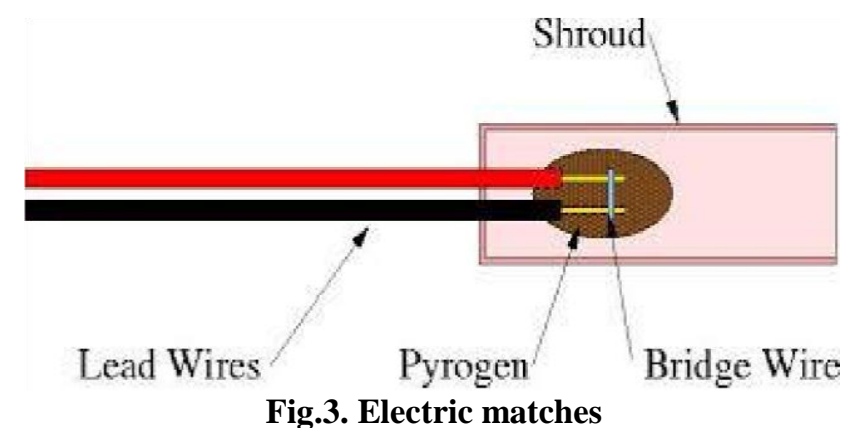

IV. TOTAL IMPULSE MEASURING SYSTEM

The solid propellant motor, when fired, produces a thrust force which makes a bending moment. A sensitive ultrasonic sensor calibrated the initial and final distance (Deflection) in terms of millimetre, proportional to the bending moment as shown in figure 4 . The bending moment is directly proportional to the thrust force of the solid propellant motor.

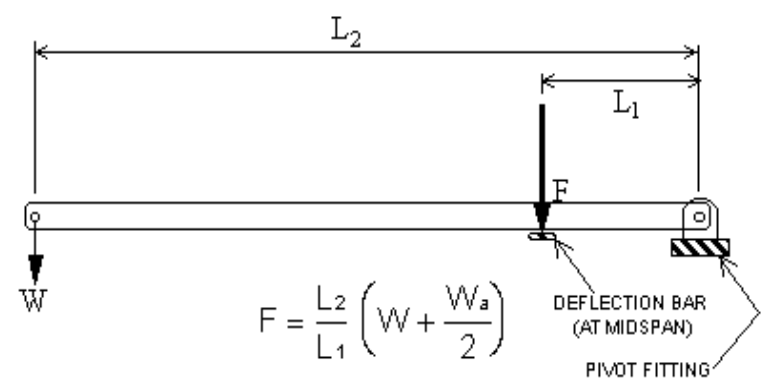

Fig.4.a Total impulse measuring system (experimental setup)

These are the following tools required for the proposed impulse measuring system.

1. Thermocouple with digital indicator

2. DC Gear motor (to plot the amplitude variation of thrust versus time)

\section{Ultrasonic Sensor, Arduino circuit board}

\section{EXPERIMENTAL CALCULATION}

The solid propellant is inserted in the proper location where the force is assigned to be found (at the tip of the beam) as shown in figure 4 . Four propellant combinations are tested here. The maximum temperature value and the bending moment are found for the calculation purpose. The effective burning time are noted. The small scaled propellant motor with length $12 \mathrm{~cm}$, Diameter $2.5 \mathrm{~cm}$, Exit Nozzle Diameter $0.003 \mathrm{~m}$, Empty Motor weight 20 grams are used. The following table 1 shows the readings taken in all 4 tests.

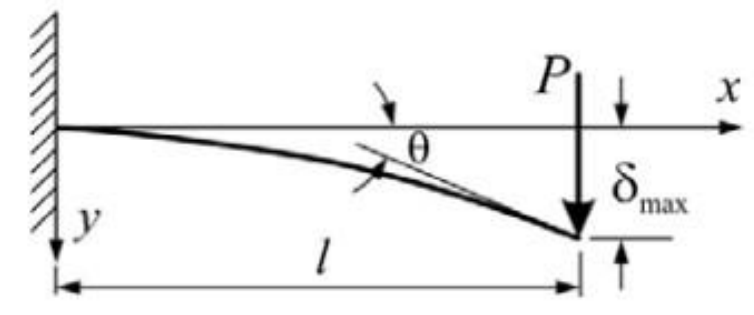

Fig.4.b Total impulse measuring system (Beam Deflection) 
Table No: 1 Test readings for different propellant combination

\begin{tabular}{|c|c|c|c|c|c|}
\hline $\begin{array}{l}\text { SI } \\
\dot{\mathrm{N}}\end{array}$ & Test & $\begin{array}{c}\text { Propellant } \\
\text { ratio (in } \\
\text { grams) }\end{array}$ & $\begin{array}{l}\text { Motor } \\
\text { Weight }\end{array}$ & $\begin{array}{c}\text { Burning } \\
\text { time }\end{array}$ & $\begin{array}{l}\text { Temp. } \\
\text { reading } \\
\text { (deg. } \\
\text { C) }\end{array}$ \\
\hline 1 & $\begin{array}{c}\mathrm{KNO} 3+\mathrm{C} 12 \mathrm{H} \\
22 \mathrm{O} 11 \text { (ratio } \\
65 / 35 \text { ) } \\
\end{array}$ & $\begin{array}{c}\text { Oxidiser:45 } \\
\text { Fuel:25 }\end{array}$ & $\begin{array}{c}100 \\
\text { grams }\end{array}$ & $4 \mathrm{sec}$ & 710 \\
\hline 2 & $\begin{array}{c}\text { KNO3 } \\
+\mathrm{C} 12 \mathrm{H} 22 \mathrm{O}_{11} \\
+ \text { Aluminium }\end{array}$ & \begin{tabular}{|c} 
Oxidiser:45 \\
Fuel:25 \\
Aluminium: \\
10
\end{tabular} & $\begin{array}{c}100 \\
\text { grams }\end{array}$ & $4 \mathrm{sec}$ & 594 \\
\hline 3 & $\begin{array}{c}\mathrm{KNO}_{3}+ \\
\mathrm{C} 12 \mathrm{H}_{2} 2 \mathrm{O}_{11}+ \\
\text { sulphur }\end{array}$ & $\begin{array}{c}\text { Oxidiser:4 } 5 \\
\text { Fuel:25 }\end{array}$ & $\begin{array}{c}90 \\
\text { grams }\end{array}$ & $3 \mathrm{sec}$ & 547 \\
\hline 4 & $\begin{array}{l}\mathrm{KNO}_{3}+\mathrm{C} 12 \mathrm{H} \\
22 \mathrm{O}_{11}+\text { sulphu } \\
\text { r+Aluminiu m }\end{array}$ & $\begin{array}{l}\text { Oxidiser: } \\
40 \\
\text { Fuel:30 }\end{array}$ & $\begin{array}{c}90 \\
\text { grams }\end{array}$ & $3 \mathrm{sec}$ & 510 \\
\hline
\end{tabular}

Impulse is the integral of the solid propellant motor's thrust over time. The quantity of energy available from a propellant charge is determined by the chemical nature of the oxidizer and fuel molecules, as well as by the chemical nature of the reaction gas products. Specific impulse, which is an effective measure of the performance of various propellant systems compared to one another. The more efficient propellant provides higher specific impulse. Specific impulse is the impulse per unit mass of propellant, measured in seconds.

$$
\mathrm{I}=\int F d \mathrm{t}
$$

By simplifying this equation with impulse-momentum theorem,

Total impulse $=($ Thrust $*$ Burning time $)$

$$
\text { Thrust, } \mathrm{F}=m * \mathrm{~V}_{\mathrm{e}}
$$

Where, $\mathrm{V}_{\mathrm{e}}$ is the exhaust velocity at the nozzle exit $(\mathrm{m} / \mathrm{s})$ $m$ is the mass flow rate $(\mathrm{kg} / \mathrm{s})$

Specific Impulse $=($ Total Impulse $/$ Total burning propellant weight)

$$
\mathrm{I}_{\mathrm{sp}}=\mathrm{Ve} / \mathrm{g}
$$

Where, $g$ is the gravitational acceleration at sea level on earth $\left(9.807 \mathrm{~m} / \mathrm{s}^{2}\right)$

Mass flow rate is defined as the ratio of mass flow through a given point on a unit time. Here, it is the result of burning propellant.

Where, r-burning rate

$$
m=\Omega \mathrm{p} * \mathrm{~A} * \mathrm{r}
$$

A-propellant burning surface area

¿p- Density of propellant

$m$-Mass flow rate

Mass flow rate $=($ Propellant mass $/$ Rocket Operation

Duration)

Thrust $=\left(\right.$ Specific impulse ${ }^{*}$ Gravity*mass flow rate $)$ Effective Exhaust velocity $=$ (specific impulse* Gravity) The calculations of specific impulse and other related terms are done with the above mentioned formulae.

\section{RESULT}

There are four different propellant combinations are tested for finding out specific impulse. In which the test 4 $\left(\mathrm{KNO}_{3}+\mathrm{C}_{12} \mathrm{H}_{22} \mathrm{O}_{11}+\right.$ sulphur+aluminium powder combination) has more $\mathrm{I}_{\mathrm{sp}}$ value than that of others. In test 4 , the burning time, total impulse, and effective exhaust velocity is more as compare with others. In addition, it is understood that, the properties of adding aluminium with the fuel oxidizer combination provided more thrust and effective exhaust velocity. The test 4 propellants are chosen for the future experimental studies because of its better performance. The proposed impulse measuring system is the simple tool helps us to find the propellant properties and its performance in the easiest way.

\section{REFERENCES}

1. S. S. Penner, chemical propellants, California Institute of Technology, Pasadena, California

2. M. H. Ziraksaz, How to Design, Build and Test Small Solid Propellant Rocket motor (Part one) (Science and Research Branch, Islamic Azad University, Tehran, Iran, 45th AIAA/ASME/SAE/ASEE Joint Propulsion Conference \& Exhibit 2 - 5 August 2009, Denver, Colorado.)

3. Isakowitz, Steven J. International Reference Guide to Space Launch Systems. Washington, D.C.: American Institute of Aeronautics and Astronautics (AIAA), 1999.

4. Sellers, Jerry J. et. al., "Investigation into Cost-Effective Propulsion System Options for Small Satellites." Journal of Reducing Space Mission Cost. Vol. 1, No. 1, 1998.

5. Wertz, James R. and Wiley J. Larson. Space Mission Analysis and Design. Third edition. Dordrecht, Netherlands: Kluwer Academic Publishers, 1999.

6. Total impulse measuring system for solid propellant rocket engine technical documentary report no. Rpl-tdr64-110, v. C. Plane, a division of north american aviation, inc.6633 canoga avenue, canoga park, california

7. Einstein, Albert. Relativity: The Special and the General Theory. New York, NY: Bonanza Books, 1961. Distributed by Crown Publishers, Inc. for the estate of Albert Einstein.

8. Forward, Robert L. and Robert P. Hoyt. "Space Tethers." Scientific American. pp. 86-87. February, 1999.

9. Humble, Ronald., Gary N. Henry, and Wiley J. Larson. Space Propulsion Analysis and Design. New York, NY: McGraw-Hill, Inc., 1995

\section{AUTHORS PROFILE}

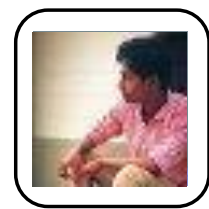

Raghu Dev $\mathbf{S} \mathbf{K}$ was a student of Kalasalingam Academy of Research and Education and is currently working as production engineer in Chennai, India

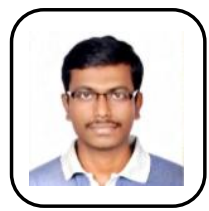

J. Sarathkumar Sebastin working as Assistant Professor in Aeronautical Engineering, Kalasalingam Academy of Research and Education. The author has published papers in the areas of Solid propellants, UAV and propulsion. 